\title{
The Effect Of Applying Picture Word Inductive Model (PWIM) on the Students' Achievement in Writing Descriptive Text
}

\author{
Ambar Wulan Sari ${ }^{*}$ and Santika² \\ ${ }^{1,2}$ Universitas Muhammadiyah Sumatera Utara, Medan, Indonesia \\ *ه(email), ambarwulan@umsu.ac.id
}

\begin{abstract}
The objective of this research was to find out the effect of applying picture word inductive model (PWIM) on students' achievement in writing descriptive text.The method of research was the experimental research method. The population of this research was taken from the eight grade and the second year students of junior high school at MTs. Islamiyah Medan Jl.Suluh No. 71 D, Sidorejo Hilir, Medan Tembung, Medan, Sumatera Utara. at academic 2017/2018 with the total population were 84 students. The sample consisted of 30 students were taken by using purposive sampling. The classes were divided into one group, namely experimental group used in one-group pretest-posttest.Therefore, the research was taken one class as the experimental class.The experimental group was taught by applying picture word inductive model (PWIM). The instrument of research was written test (pretest-postest). The researcher were given treatment by PWIM strategy. The instrument of collecting data was written test which was given picture to make a descriptive text as the test items. The data analysis was using T-test. The result showed that the students mean in teaching descriptive text before taught applying Picture word inductive model (PWIM) is only 47.5 while the students mean in teaching descriptive text after the being taught applying picture word inductive model (PWIM) is 85.5 it was improved. The data were analyzed by using t-test formula. with the t-test analysis that used by researcher, with the significant level 0.05 . The result of the data showed that $5.71>2.04$ with degree of freedom $(\mathrm{df})=$ N-1 (30-1). The final hypothesis showed that $\mathrm{H}_{0}$ was rejected and $\mathrm{H}_{\mathrm{a}}$ was accepted. It proves that Picture Word Inductive Model (PWIM) significantly effect to the students' achievement in writing descriptive text.
\end{abstract}

Keywords: Picture Word Inductive Model (Pwim), Writing, Descriptive Text

\section{INTRODUCTION}

There are four basic skills in the English learning such as listening, reading, speaking, and writing. Listening and reading includes passive or receptive skills, while speaking and writing includes active or productive skills (Harmer, 2001:199, 246).Writing, as part of communication, is an important subject which needs to express and share their ideas, knowledge, feeling and information. Harmer (2001:3) define that writing is a form of communication to deliver through or to express feeling through written form. When begin to write, the writer needs to get and organize the idea, write the paragraph, revise and write again into good composition.

Linse (2006:98) argues that writing is a combination of process and product of discovering ideas, putting them on paper and working with them until they are presented in manner that is polished and comprehensible to readers. Writing is one of the language skills which must be taught to junior high school students. In syllabus of junior high school for grade eight the goal of teaching writing is to make easy the students to writesimple text by using accurate vocabulary and appropriate grammar. It is clearly noted in KTSP curriculum that the students should be able to express the meaning of written text itself. In KTSP curriculum there are kinds of the texts that must be taught to junior high school, such as; descriptive text, narrative text, procedure text and else. Here the researcher used the descriptive text in her research because the descriptive text is one of the texts that persuade the students to be more creative in expressing whatever they see in around them.

Writing descriptive text is taught by researcher in order student to know how to decsribe themselves or their surrounding in a simple way. Descriptive text is a type of text that has a function to describe particular person place and thing. Students are expected to be able to write a descriptive text to convey their ideas in their mind into written form which discussed. In fact, many Indonesian students face many difficulties when they start writing especially about descriptive text. The teacher of MTs.Islamiyah Medan usually asks the students to write sentence as many as they can but they do need to know 
how to make their students write as many as they can. They are confused about how they will write their idea and arrange it into good descriptive text. It happens because usually the teacher only given them examples of descriptive text. After that they should write or produce their own descriptive text with limited guidance. Teacher do not want to try another strategy in their teaching activity of writing. Teacher is seldom to teach the students how the process to write a text until become a good paragraph. As a result, most of the students accomplish the task through copying texts that they find from internet. In other words, the students do not produce the texts based on their writing ability.

Based on the researcher's observation, the researcher found that the students spent much time to think what they had to write. Many students cannot get and generate their own idea. Some students have idea but cannot express it in their own sentences. They also have difficulties in arranging the idea into good order to form a good descriptive text. They also lack of vocabularies related to the idea that they want to write. As the evidence the interviewed has been done with the english teacher of MTs Islamiyah Medan, to know teacher's perception about the students' writing problems. The teacher admitted that many student fail in achieving writing skill proved from the score of Criteria Standard Minimum is 75. Mostly students' writing score are lowest than it, means that they are poor in writing. The other students' writing problem especially in wiritig descriptive, student confused to find ideas, if they are asked to write just by giving a direction without relevant object that used as visual ideas stimulation, then they felt difficult organize their ideas well in english.

Based on the problem above, the researcher interested to apply "Picture Word Inductive Model (PWIM)" to solve students' problem in writing. There are new strategies that are created and applied in teaching language skills. Picture Word Inductive Model (PWIM) is one of strategies that can be applied to various level of students. It is also can be focused on all language skill, specifically reading and writing skills.

The researcher applied Picture Word Inductive Model (PWIM) as the strategy in developing the students writing ability. Jiang (2015) who believes that the fundamental tenet of PWIM is its use of "pictures as a stimulus for language experience activities" in classrooms to teach young students learning to read and write. The model is designed to capitalize on children's ability to think inductively. The PWIM enables them to build generalizations that form the basis of structural and phonetic analysis. And it respects their ability to think. Through this strategy, students can compose their writing from the basic aspect such as vocabulary. On the other hand, Picture Word Inductive Model (PWIM) is used to guide the students to develop their imagination and idea to make a sentence.Calhoun (1999:4) states that the Picture Word Inductive Model is designed to teach reading, writing, and the language system. Because of that, this strategy is predicted can help the students to solve their problems in writing, especially in writing descriptive texts.
This strategy leads the students to identify each object in a picture that they will describe. Through this strategy, the students will be easier to develop their descriptive writing based a picture. The Picture Word Inductive Model (PWIM) strategy is the combination between picture and word. According to Harmer (2004:67), "just as music can provoke creativity in students - especially those who are particularly responsive to auditory stimuli - so too pictures work really well as spurs to written production". So, by giving the combination of picture and word to the students, their creativity will run very well,those combination can also stimulate students' ideas in writing.

Writing skill of the eighth grade students at MTs.Islamiyah Medan stillneeds to be developed. This situation is caused by several reasons; one of themis dealing with the media that are given in writing class. The teaching techniquemay not be appropriate with what students want. This situation may leadstudents have less passion to learn. Students actually need suitable teaching technique in order tomake them motivated to learn. If the teaching technique is appropriate, students will enjoy the lesson. In this case, the researcher offers a solution. It is teaching writing through Picture Word Inductive Model (PWIM).

Picture Word Inductive Model (PWIM) offers interesting and easy way in writing. It is easier for them to get and arrange the idea. Students are working in group and they learn how to share their idea and combine it with others' idea in a group, individual or pairs. It will guide students to generate idea to write. They will not be confused about what will they write anymore. In the process of writing descriptive text, the students of junior high school still face the difficulties. It is important for the teachers to facilitate them with an interesting strategy in order to encourage them in learning English especially writing.

This study is intended to find out the effect of teaching writing by applying PWIM (Picture Word Inductive Model) strategy on the student achievement in writing descriptive text. In teaching writing, the teacher had to be able to attract the students attention in order that they can write a good text.Teaching writing descriptive text by applying PWIM (Picture Word Inductive Model) strategy is very helpful for the students, especially the eighth grade students of MTs.Islamiyah Medan. By applying the PWIM (Picture Word Inductive Model)strategy, the students are able to write a good text and helps students to elicit the ideas to improve their writing.It is expected that applying PWIM (Picture Word Inductive Model) strategy in teaching writing would effect the students achievement in writing descriptive text.

\section{METHOD}

This research was conducted at MTs. Islamiyah Medan, Jl. Suluh No. 71D, Sidorejo Hilir, Medan Tembung, Medan, Sumatera Utara in academic year $2017 / 2018$. The reason for choosing this school because the researcher had interviewed and observed in this school and it found that the students' ability in this school in 
learning english was still low, especially in learning descriptive text. The students are not exciting to write and it is hard for them to develop their ideas in writing descriptive text and researcher had never conducted before.

This research was conducted by using experimental research design, namely one group pretest post-test. It deal with quantitative research. In this method the sample was given a treatment based on the variable research. The experimental group were teach by Picture Word Inductive Model. The experimental group was given pre-test before doing the treatment.

In the experimental group, the treatment was taught byPicture Word Inductive Model. After the treatment, the experimental group was given post-test. The design was applied in order to investigate the effect of Picture Word Inductive Model (PWIM) on students achievement in writing descriptive text.

In collecting the data, some the steps were applied as follows:

1.Giving pre-test to the students to experimental group

2.Giving treatment to experimental group by applying

Picture Word Inductive Model (PWIM)

3. Giving post-test to experimental group

4.Listing the score of pre-test and post-test into table for experimental group

The technique for analyzing data:

1.Reading the student's answer

2.Identifying the student's answer

3.Scoring the student's answer

\section{RESULT AND DISCUSSION}

By consulting analyzing of the data, it is clearly stated that there was an effect of Picture Word inductive Model (PWIM) on the students' achievement in writing descriptive text. It can be simple see from the differences of mean score of Pre-test and Post-test in experimental class. They were 47.5 in pre-test and 85.5 in post-test of experimental class, the mean of pre-test increases after Picture Word Inductive Model (PWIM) from 47.5 to 85.5.

From the result of calculation, it is obtained the value of the $t$ observation $\left(t_{a}\right)$ is 5.71 the degree of freedom (df) is 29 (obtained from N-1) $=(30-1=29)$. the researcher used the degree of significance of $5 \%$. In the table of significance, it can be seen the df 29 and the degree of significance of $5 \%$ is 2.04 . If compared with tobserve the result is 5.71> 2.04

According Sudijono if the result of calculation $t_{a}$ (t-observation) is higher than(t-table), $\mathrm{t}_{\mathrm{a}}>$; the null hypothesis (Ho) is rejected. If the result of calculation $t_{a}(t-$ observation) is lower than (t-table) $t_{a}<$; the null hypothesis is accepted . since the scores obtained from the result of calculating, the alternative hypothesis $\left(\mathrm{H}_{\mathrm{a}}\right)$ is accepted and the null hypothesis (Ho) is rejected. In other word, the writer hypothesis is accepted. It mean that there is siginificance effect of applying picture word inductive model (PWIM) on students' achievement in writing descriptive text.
Based on the previous discussion on the background of this study, the hypothesis was formulated as follows : Ha : There is significant effect of Picture Word Inductive Model (PWIM) on the students' achievement in writing descriptive text. Ho : There is no significant effect of Picture Word Inductive Model (PWIM) on the students' achievement in writing descriptive text.

\section{CONCLUSION}

From data analysis, the objective of this research was to know if there was an effect of applying Picture Word Inductive Model (PWIM) on students' achievement in writing descriptive text at the second grade of MTs.Islamiyah Medan. The score of descriptive text test before taught by applying Picture Word Inductive Model (PWIM) is less because the mean of total score of 30 students is only (47.5). After they got treatment, the mean of descriptive text is (85.5). It was improved, with the $t$ test analysis that used by researcher, the result is (5.71).

After analyzing the data, it was found that there was a significant effect of applying picture word inductive model (PWIM) on the students' achievement in writing descriptive text, which was prove from the result of the test showed that the tobserve was 5.71 with degree of freedom (df) 29 at the level significant $0.05 \%$ was at 2.04 . It mean that tobserve was higher than ttable $(5.71 \geq 2.04)$. $\mathrm{Ha}$ is accepted if tobserve was higher than ttable and $\mathrm{HO}$ is rejected if ttable is lower than tobserve. So it can be concluded that $\mathrm{Ha}$ is accepted, tobserve was higher than ttable $(5.71 \geq 2.04)$. It meant that there was a significant effect of applying picture word inductive model (PWIM) on the students' achievement in writing descriptive text.

\section{REFERENCES}

[1] Anderson, M. \& Anderson, K. (2003). Text Types in English 3. South Yarra: Macmillan.

[2] Andriani, Lina.S. (2015). The Use Of Picture Word Inductive Model (PWIM) Strategy To Improve Students' Writing Skill Of Recount Text (An Action Research of the Eighth Graders of Junior High School 2 Semarang in the Academic Year of 2014/2015). A Final Project: English Departement of UNNES. Unpublished.

[3] Cabassa, L.A. (2009). Maya West Writing Project: Picture Word Inductive

Model

PWIM. Available..online..at..http://www.slideshare.net/ir marisrn/picture word-inductive model.

[4] Calhoun, E.F. (1999). Teaching Beginning Reading and Writing with the Picture Word Inductive Model (PWIM).

[5] Chandler,Daniel. (2005).An Introduction to GenreTheory.Onlineathttp://www.aber.ac.uk/medi a/Documents/intgenre/intgenre.

[6] Calhoun, E.F. (1999). Teaching beginning reading and writing with the Picture Word Inductive Model (PWIM). Alexandria, VA: Association for 
supervision and curriculum development. (online). Available at http://saidnazulfikar.files.wordpress.com/2008/04/ teaching-beginning-readingandwriting- with-thepicture-word-inductive-model.pdf.

[7] Colon, A and Martinez, S. (2013). Building the Language with Picture Word Inductive Model. Fordam University: NYC RBERN at Fordam University.

[8] Fredericks, S.(2009).Picture Word Inductive Model.Available online at https://www.pinterest.com/pin/236720524137 830938/

[9] Fulcher, G. (2003). Testing Second Language Speaking. Great Britain: Longman

[10]Gerot, Linda and Wignel, Peter. (1994). Making Sense of Functional Grammar. Australia.

[11] Gerd Stabler. Harmer, Jeremy. 2001. The Practice of English Language Teaching (3rd Ed.). Essex: Pearson Education Ltd.

[12] Harmer, Jeremy. (2004). How to Teach Writing. Essex: Pearson Education Ltd.

[13] Hedge, Tricia. (2000). Teaching and Learning in the Language Classroom. New York: Oxford University Press.

[14] Hyland, K. (2004). Second Language Writing. New York: Cambridge University Press.

[15]Hughes, A. (2003).Testing for Language Teachers. 2nd Ed. Cambridge: Cambridge University Press.

[16] Jiang, Xuan and K. Perkins. (2013). 'A conceptual paper on the application of the picture word inductive model using Bruner's constructivist view of learning and the cognitive load theory'. Interdisciplinary Journal of Teaching and Learning, Vol. 3. No. 1: 8-17.

[17] Jiang, X. (2015). Exploring Seventh Graders' Perceptions of the Picture-Word Inductive Model in their Narrative Writing in China. Saint Thomas University. USA.

[18] Knapp, Peter., \& Megan Watkins. (2005). Genre, Text, and Grammar. Sidney: University of New South Wales.

[19]Linse, C.T. (2006). Practical English language teaching: Young learners. New York: Mc Graw Hill.

[20] Mawaddah, Laili. (2009). The Effectiveness Of Mind Mapping Strategy In Teaching The Students To Write Descriptive Text (An Experiment Of The Eighth Grade Students Of Smp N I Pegandon Kendal In The Academic Year Of 2008/2009. A Final Project:English Departement of UNNES. Unpublished.

[21] Marbun, Indah C.R \& Sumarsih. (2015). "The Effect of Using Picture Word Inductive Model on Students' Achievement in Writing Procedure Text". Junior High School 32 Medan: English Language and Literature Department of UNIMED.

[22] Meiranti,Wahyu.(2016). The Use Of Picture Word Inductive Model In Developing Students' Descriptive Text Reading Ability At The First Grade Of SMPN 3 Natar Lampung Selatan. Faculty Of Teacher Training And Education Lampung University Bandar Lampung.

[23] Meyers, Alan. (2005). Gateways to Academic Writing. New York: Pearson Education, Inc.

[24] Palmer, Sue. (2003). How to Teach Writing Across the Curriculum at Key Stage 1. New York: David Fultan Publishers.

[25] Pardiyono. (2007). Pasti Bisa! Teaching Genre Based Writing. Yogyakarta: CV. Andi Offset.

[26]Regina, L, Smallery, Mary, K, Routten. (2003). Refining Composition Skill Rethoric nd Grammar Skill.NewYork: Mccmilan Publlishing Company.

[27] Sanggam and Kisso. (2008). Generic Text Structure. Yogyakarta. Graha Ilmu.

[28] Sari, Dwi.A. (2017). The Effect Of CollectOrganize-Write (Cow) Strategy On The Students' Achievement In Writing Descriptive Text at SMP Nurul Hasanah, Jalan Amal Baksti Pasar VII Tembung. A Final Project: Faculty Of Teachers' Training And Education University Of Muhammadiyah Sumatera Utara Medan.

[29] Sepyanda, Marsika, Mukhaiyar, Kusni.( 2013). The Effect Of Picture Word Inductive Model (Pwim) And Students' Self-Efficacy Toward Their Writing Skill Of Descriptive Texts At Grade X of SMA Negeri 1 IX Koto Sungai Las. Pascasarjana Universitas Negeri Padang. Sudijono, Anas. 2012. Pengantar Statistik Pendidikan. Jakarta: PT.RajaGrafindo Persada Sugiyono. 2010. Metode Penelitian Kuantitatif, Kualitatif dan R\&D. Bandung: Alfabeta.

[30] Siregar, F. S. (2010). Improving students writing skill through cooperative learning strategy at bilingual class of Panca Budi Medan (Master's thesis, UNIMED Digital Repository).

[31] Suprijono, A. (2009). Cooperative Learning. Pustaka: Yogyakarta 